\title{
MODEL KINETIKA INHIBISI SUBSTRAT PADA PERTUMBUHAN KLUYVEROMYCES LACTIS
}

\author{
Akbarningrum Fatmawati \\ Jurusan Teknik Kimia, Fakultas Teknik, Universitas Surabaya \\ Jalan Raya Kalirungkut Surabaya 60292 \\ Email: akbarningrum@ubaya.ac.id
}

\begin{abstract}
Abstrak
Limbah industri makanan seperti whey dapat dimanfaatkan sebagai substrat dalam proses fermentasi. Kluyveromyces lactis adalah salah satu ragi yang dapat memetabolisme kandungan laktosa dari whey. Pada perancangan proses fermentasi sangat diperlukan data kinetika dan model pertumbuhan dari mikroorganisme. Penelitian ini dilakukan untuk mengetahui model kinetika pertumbuhan batch Kluyveromyces lactis FNCC 3024 pada substrat laktosa, glukosa dan galaktosa. Konsentrasi substrat divariasi sebesar 5, 10, 20, 50, 100 dan 150 g/L. Profil pertumbuhan ragi pada substrat glukosa dan laktosa menunjukkan adanya inhibisi substrat sedangkan profil pertumbuhan pada substrat galaktosa inhibisi substrat tidak tampak. Model kinetika inhibisi subtrat non-kompetitif lebih tepat digunakan untuk substrat glukosa dan laktosa dengan kuadrat beda yang cukup kecil yaitu 9,956 x 10-3 untuk glukosa dan 3,777 x $10^{-3}$ untuk laktosa. Model kinetika Monod untuk substrat galaktosa memberikan jumlah kuadrat residual terkecil yaitu $1,358 \times 10^{-3}$. Laju pertumbuhan spesifik maksimum yang dihasilkan dan pemodelan untuk substrat glukosa, laktosa dan galaktosa berturut-turut adalah $0,295,0,265$ dan 0,147 jam-1.
\end{abstract}

Kata kunci : kinetika, pertumbuhan, inhibisi, substrat, Kuyveromyces lactis

\begin{abstract}
Food industry waste such as whey may be utilized as substrates in fermentation processes. Kluyveromyces lactis is yeast that can metabolize the lactose content of whey. In fermentation process design, the kinetics data and growth model of the microorganism are essential. This research was done to identify the growth kinetic model of Kluyveromyces lactis FNCC 3024 in lactose, glucose, and galactose substrates. Substrate concentration was varied as 5, 10, 20, 50, 100, and $150 \mathrm{~g} / \mathrm{L}$. Yeast growth profile in glucose and lactose substrates indicated substrate inhibition effect, while the growth profile in galactose substrate did not. Noncompetitive substrate inhibition kinetic model was more suitable for glucose and lactose models, with a relatively small sum of squares of errors, namely $9.956 \times 10^{-3}$ for glucose and $3.777 \times 10^{-3}$ for lactose. Monod kinetic model for galactose substrate produced the lowest sum of squares of errors, namely $1.358 \times 10^{-3}$. The maximum specific growth rate obtained from the modeling for glucose, lactose, and galactose substrates were $0.295,0.265$, and 0.147 hour $^{-1}$.
\end{abstract}

Keywords: kinetics, growth, inhibition, substrate, Kluyveromyces lactis 


\section{Pendahuluan}

Proses fermentasi merupakan proses yang menguntungkan untuk menghasilkan suatu produk. Pemanfaatan limbah industri makanan dengan kandungan BOD yang masih tinggi sebagai substrat fermentasi merupakan salah satu keuntungan proses fermentasi. Whey merupakan limbah dari industri keju yang masih mengandung gula laktosa dan komponen lain. Dari proses pembuatan keju bisa dihasilkan whey sebesar $85-95 \%(\mathrm{v} / \mathrm{v})$ setelah pengendapan kasein, dan whey tersebut masih mengandung 55\% nutrien susu. Komposisi dari whey antara lain adalah 92\% air, 5\% laktosa, 1,9\% protein dan lemak, $0,9 \%$ garam mineral dan sisanya berupa vitamin (Ghaly dkk., 2005). Pemanfaatan whey dapat dilakukan untuk media fermentasi, salah satunya untuk menghasilkan etanol. Penelitian fermentasi etanol dari whey telah dilakukan oleh beberapa peneliti (Ghaly dan Taweel, 1994, 1997; Kargi dan Ozmihci, 2005; Zafar dan Owais, 2006). Kluyveromyces lactis adalah salah satu ragi yang dapat memetabolisme kandungan laktosa dan whey. Model kinetika pertumbuhan mikroorganisme sangat diperlukan dalam perancangan proses fermentasi. Model tersebut dapat digunakan untuk memprediksi pengaruh parameter-parameter operasi fermentasi terhadap laju pertumbuhan, konsentrasi sel dan laju penggunaan substrat oleh sel. Penentuan parameter kinetika pertumbuhan lebih sulit dilakukan pada medium kompleks seperti whey. Oleh sebab itu pada penelitian ini dilakukan penentuan model kinetika pertumbuhan Kluyveromyces lactis FNCC 3024 pada medium sintetis dengan substrat laktosa, glukosa dan galaktosa. Konsentrasi substrat yang rendah akan menghasilkan laju pertumbuhan yang rendah sedangkan konsentrasi substrat yang tinggi akan menghambat pertumbuhan. Pada penelitian ini digunakan model kinetika inhibisi substrat untuk mengetahui pengaruh konsentrasi substrat terhadap laju pertumbuhan spesifik Kluyveromyces lactis FNCC 3024.

Pada sistem batch, pertumbuhan mikroorganisme terdiri dari beberapa fase yaitu fase lag, eksponensial, stasioner, penurunan laju pertumbuhan dan kematian. Pada fase eksponensial, pertumbuhan sel mengikuti persamaan orde 1 sebagai berikut:

$\frac{d X}{d t}=\mu X$
Persamaan (1) menunjukkan bahwa peningkatan material sel sebanding dengan konsentrasi sel. Laju pertumbuhan spesifik $(\mu)$ merupakan fungsi konsentrasi substrat. Hubungan antara substrat dan laju pertumbuhan spesifik paling sederhana adalah persamaan Monod sebagai berikut:

$\mu=\frac{\mu_{m} S}{K_{S}+S}$

Tetapi, pada konsentrasi substrat awal yang tinggi, laju pertumbuhan spesifik sel akan menurun. Hal ini disebabkan oleh inhibisi substrat terhadap pertumbuhan sel. Oleh sebab itu model laju pertumbuhan spesifik hams memperhitungkan pengaruh inhibisi pada konsentrasi substrat yang tinggi. Model inhibisi substrat tersebut antara lain adalah sebagai berikut (Shuler dan Kargi, 1992):

- Noncompetitive substrate inhibition:

$\mu=\frac{\mu_{\mathrm{m}}}{\left(1+\frac{K_{S}}{S}\right)\left(1+\frac{S}{K_{I}}\right)}$

- Competitive substrate inhibition:

$\mu=\frac{\mu_{\mathrm{m}} \cdot \mathrm{S}}{K_{S}\left(1+\frac{S}{K_{I}}\right)+S}$

\section{Metodologi}

Pada penelitian ini mikroorganisme yang digunakan adalah ragi Kluyveromyces lactis FNCC 3024 yang diperoleh dari PAU UGM.

\section{Persiapan Inokulum dan Fermentasi} Inokulum dari ragi Kluyveromyces lactis FNCC 3024 diperoleh dengan membiakkan ragi tersebut pada MRS agar pada suhu $30^{\circ} \mathrm{C}$ selama 48 jam. Kemudian sebanyak 2 koloni dari biakan tersebut dipindahkan dalam medium cair dengan komposisi substrat (laktosa, glukosa atau galaktosa) $20 \mathrm{~g} / \mathrm{L}$, dan mineral medium, yaitu $\left(\mathrm{NH}_{4}\right)_{2} \mathrm{SO}_{4} 5 \mathrm{~g} / \mathrm{L}, \mathrm{K}_{2} \mathrm{SO}_{4} 6,58 \mathrm{~g} / \mathrm{L}, \mathrm{KH}_{2} \mathrm{PO}_{4} 3$ g/L, dan $\mathrm{MgSO}_{4} \cdot 7 \mathrm{H}_{2} \mathrm{O}$ 0,5 g/L. Pertumbuhan dalam medium cair tersebut dilakukan pada labu erlenmeyer yang digoyang pada shaker dengan kecepatan $120 \mathrm{rpm}$ selama 24 jam. Inokulum sebanyak $10 \% \mathrm{v} / \mathrm{v}$ dimasukkan dalam medium fermentasi dengan variasi konsentrasi substrat 5, 10, 20, 50, 100 dan 150 g/L. Selain substrat gula, medium fermentasi mengandung mineral dengan 
komposisi seperti pada media inokulum, vitamin steril, serta trace element. Kandungan dari trace element antara lain adalah EDTA 15 $\mathrm{mg} / \mathrm{L}, \mathrm{ZnSO}_{4} .7 \mathrm{H}_{2} \mathrm{O}$ 4,5 mg/L, $\mathrm{CoCl}_{2} .6 \mathrm{H}_{2} \mathrm{O} 0,3$ $\mathrm{mg} / \mathrm{L}, \mathrm{MnCl} 2.4 \mathrm{H}_{2} \mathrm{O} 1 \mathrm{mg} / \mathrm{L}, \mathrm{CuSO}_{4} .2 \mathrm{H}_{2} \mathrm{O} 0,3$ $\mathrm{mg} / \mathrm{L}, \mathrm{CaCl}_{2} .2 \mathrm{H}_{2} \mathrm{O} \quad 4,5 \mathrm{mg} / \mathrm{L}, \mathrm{FeSO}_{4} .7 \mathrm{H}_{2} \mathrm{O} 3$ $\mathrm{mg} / \mathrm{L}, \mathrm{NaMoO}_{4} .2 \mathrm{H}_{2} \mathrm{O} 0,4 \mathrm{mg} / \mathrm{L}, \mathrm{H}_{3} \mathrm{BO}_{3} 1 \mathrm{mg} / \mathrm{L}$ dan KI 0,1 mg/L. Fermentasi dilakukan pada volume medium sebesar $300 \mathrm{~mL}$ dalam erlenmeyer $500 \mathrm{~mL}$ yang digoyang pada shaker dengan kecepatan 120 rpm. Pengambilan sampel dilakukan tiap jam untuk mengukur konsentrasi sel selama pertumbuhan dengan menggunakan spektrofotometer pada panjang gelombang $660 \mathrm{~nm}$.

\section{Perhitungan laju pertumbuhan spesifik} dan parameter kinetika

Laju pertumbuhan spesifik rata-rata dihitung dengan mengintegralkan persamaan (1) sehingga diperoleh persamaan:

$\mu=\frac{\ln \left(X_{t}\right)-\ln \left(X_{0}\right)}{t_{t}-t_{0}}$

Dari beberapa data pertumbuhan batch untuk masing-masing konsentrasi substrat, dapat diperoleh data laju pertumbuhan spesifik. Parameter kinetika berupa $\mu_{\mathrm{m}}, \mathrm{K}_{\mathrm{s}}$ dan $\mathrm{K}_{\mathrm{I}}$ diperoleh dengan menggunakan regresi non linear metode Gauss Newton untuk masing-masing model Monod, inhibisi substrat kompetitif dan non-kompetitif. Metode ini meminimalkan jumlah kuadrat residual sebagai berikut (Chapra dan Canale, 1988):

$$
\mu_{i}-\mu\left(S_{i}\right)_{j}=\frac{\partial \mu\left(S_{i}\right)_{j}}{\partial \mu_{m}} \Delta \mu_{m}+\frac{\partial \mu\left(S_{i}\right)_{j}}{\partial K_{S}} \Delta K_{S}+\frac{\partial \mu\left(S_{i}\right)_{j}}{\partial K_{I}} \Delta K_{I}
$$

Metode terebut dapat dilakukan dengan membuai turunan pertama $\mu_{\mathrm{m}}$ terhadap masing-masing parameter sebagai berikut:

- Monod:

$$
\begin{aligned}
& \frac{\partial \mu}{\partial \mu_{m}}=\frac{\mathrm{S}}{K_{S}+S} \\
& \frac{\partial \mu}{\partial K_{S}}=\frac{-\mu_{\mathrm{m}} S}{\left(K_{S}+S\right)^{2}}
\end{aligned}
$$

$$
\frac{\partial \mu}{\partial \mu_{m}}=\frac{1}{\left(1+\frac{K_{S}}{S}\right)\left(1+\frac{S}{K_{I}}\right)}
$$

$$
\begin{aligned}
& \frac{\partial \mu}{\partial K S}=\frac{-\mu_{\mathrm{m}}}{\left(1+\frac{K_{S}}{S}\right)^{2}\left(1+\frac{S}{K_{I}}\right) S} \\
& \frac{\partial \mu}{\partial \mu_{m}}=\frac{\mu_{\mathrm{m}} \cdot \mathrm{S}}{\left(1+\frac{K_{S}}{S}\right)\left(1+\frac{S}{K_{I}}\right)^{2} K_{I}{ }^{2}}
\end{aligned}
$$

- Competitive substrate inhibition:

$$
\begin{aligned}
& \frac{\partial \mu}{\partial \mu_{m}}=\frac{\mathrm{S}}{K_{S}\left(1+\frac{S}{K_{I}}\right)+S} \\
& \frac{\partial \mu}{\partial K_{S}}=\frac{-\mu_{\mathrm{m}} S\left(1+\frac{S}{K_{I}}\right)}{\left[K_{S}\left(1+\frac{S}{K_{I}}\right)+S\right]^{2}}
\end{aligned}
$$

$\frac{\partial \mu}{\partial K_{I}}=\frac{\mu_{\mathrm{m}} \cdot \mathrm{S}^{2} \mathrm{~K}_{\mathrm{S}}}{\left[K_{S}\left(1+\frac{S}{K_{I}}\right)^{2}+S\right]^{2} K_{I}^{2}}$

Proses perhitungan parameterparameter kinetika dengan metode Gauss Newton di atas kemudian diselesaikan menggunakan program Mathcad.

\section{Hasil dan Pembahasan}

Profil pertumbuhan Kluyveromyces lactis FNCC 3024 dapat dilihat pada Gambar 1. Dari gambar tersebut dapat dilihat bahwa pertumbuhan pada substrat glukosa dan laktosa menghasilkan waktu fase lag yang hampir sama, sedangkan pada substrat galaktosa menunjukkan waktu fase lag yang lebih lama.

Konsentrasi sel maksimum yang dihasilkan pada substrat galaktosa juga lebih rendah bila dibandingkan dengan substrat glukosa dan laktosa. Dari panjangnya fase lag dan rendahnya konsentrasi sel yang dihasilkan menunjukkan bahwa galaktosa lebih sulit untuk dimetabolisme oleh Kluyveromyces lactis FNCC 3024 dibandingkan substrat glukosa dan laktosa. Dari kurva pertumbuhan pada Gambar 1 laju pertumbuhan spesifik pada masing-masing substrat dengan berbagai konsentrasi dapat diperoleh. Harga laju pertumbuhan spesifik tersebut ditampilkan pada Tabel 1. Dari tabel tersebut dapat terlihat bahwa pertumbuhan pada substrat glukosa merupakan 
pertumbuhan yang paling cepat bila dibandingkan dengan substrat laktosa dan galaktosa. Laktosa merupakan disakarida dan sel harus memecah laktosa terlebih dahulu menjadi glukosa dan galaktosa sehingga pertumbuhan pada substrat laktosa lebih lambat dibandingkan dengan pertumbuhan pada glukosa.

Kurva Pertumbuhan pada Glukosa

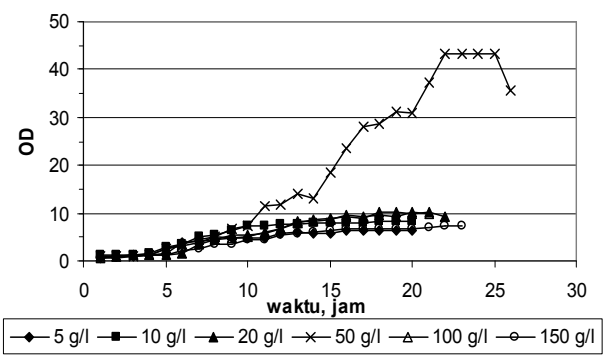

(a)

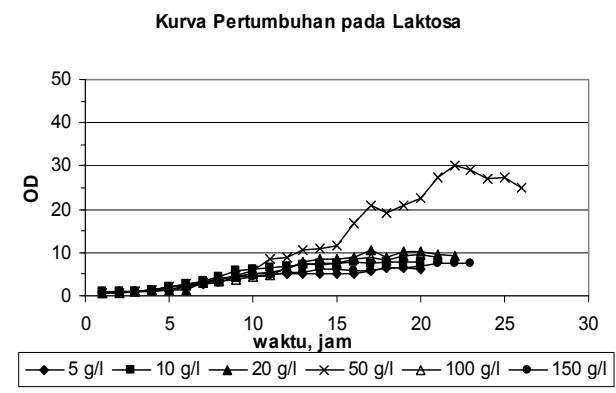

(b)

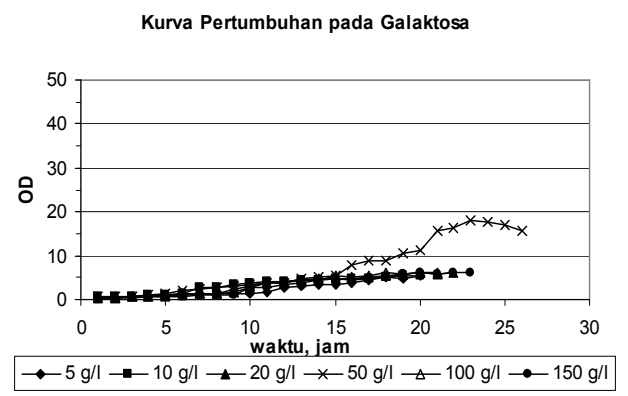

(c)

Gambar 1. Profil pertumbuhan $K$. lactis FNCC 3024 pada substrat

(a) Glukosa; (b) laktosa dan (c) galaktosa
Pada Tabel 1 juga dapat terlihat adanya penurunan laju pertumbuhan spesifik untuk substrat glukosa dan laktosa pada konsentrasi substrat yang tinggi. Sedangkan pada galaktosa, pernurunan laju pertumbuhan spesifik tersebut tidak tampak. Hal ini menunjukkan adanya inhibisi substrat glukosa dan laktosa terhadap pertumbuhan ragi Kluyveromyces lactis FNCC 3024. Oleh sebab itu pemodelan laju pertumbuhan spesifik substrat glukosa dan laktosa dilakukan dengan mengikuti model inhibisi substrat sedangkan untuk substrat galaktosa menggunakan model Monod.

Tabel 1. Pertumbuhan spesifik pada masing-masing substrat

\begin{tabular}{cccc}
\hline \multirow{2}{*}{$\begin{array}{c}\text { Konsentrasi } \\
\text { Substrat, g/L }\end{array}$} & \multicolumn{3}{c}{$\mu$, jam $^{-1}$} \\
\cline { 2 - 4 } & Laktosa & Glukosa & Galaktosa \\
\hline 5 & 0,1110 & 0,1160 & 0,1383 \\
10 & 0,1907 & 0,26667 & 0,1094 \\
20 & 0,2220 & 0,2187 & 0,1262 \\
50 & 0,1475 & 0,1540 & 0,14724 \\
100 & 0,1644 & 0,10579 & 0,1420 \\
150 & 0,1574 & 0,1720 & 0,1638 \\
\hline
\end{tabular}

Model inhibisi substrat kompetitif untuk glukosa dan laktosa tidak dapat digunakan. Pada proses perhitungan menggunakan model tersebut dihasilkan matriks singular sehingga perhitungan tidak dapat dilanjutkan Dengan demikian model inhibisi subtrat non competitive lebih tepat digunakan untuk substrat glukosa dan laktosa.

Harga parameter-parameter pertumbuhan model kinetika inhibisi substrat glukosa dan laktosa serta model kinetika Monod untuk substrat galaktosa ditunjukkan pada Tabel 2. Dari tabel tersebut dapat dilihat bahwa glukosa memberikan harga laju pertumbuhan spesifik maksimum $\left(\mu_{\mathrm{m}}\right)$ yang paling tinggi dibandingkan dua substrat yang lain. Harga laju pertumbuhan maksimum substrat galaktosa yang jauh lebih rendah bila dibandingkan dengan substrat yang lain sesuai dengan profil kurva pertumbuhan pada Gambar 1 yang menunjukkan panjangnya fase lag dan rendahnya konsentrasi sel maksimum

Tabel 2. Parameter kinetika pertumbuhan

\begin{tabular}{llcccc}
\hline \multicolumn{1}{c}{ Substrat } & \multicolumn{1}{c}{ Model } & $\mu_{m}, \mathrm{jam}^{-1}$ & $\mathrm{Ks}, \mathrm{g} / \mathrm{L}$ & $\mathrm{K}_{\mathrm{I}}, \mathrm{g} / \mathrm{L}$ & $\left(\mu_{\text {perc }}-\mu_{\text {model }}\right)^{2}$ \\
\hline Laktosa & Inhibisi substrat non kompetitif & 0,269 & 4,833 & 173,628 & 0,003777 \\
Glukosa & Inhibisi substrat non kompetitif & 0,295 & 3,877 & 147,576 & 0,009956 \\
Galaktosa & Monod & 0,147 & 1,047 & - & $0.00135 \mathrm{~S}$ \\
\hline
\end{tabular}


yang dihasilkan. Ghaly dkk. (2005) menghasilkan data percobaan $\mu_{m}$ untuk substrat laktosa oleh ragi Kluyveromyces fragilis NRS 5790 sebesar0,23 jam-1 dengan $\mathrm{K}_{\mathrm{S}}$ $1,91 \mathrm{~g} / \mathrm{L}$ serta $\mathrm{K}_{\mathrm{I}} 75 \mathrm{~g} / \mathrm{L}$. Model kinetika Monod untuk substrat galaktosa memberikan jumlah kuadrat residual yang terkecil $(1,358 \mathrm{x}$ $10^{-3}$ ) dibandingkan dengan jumlah kuadrat residual model kinetika inhibisi substrat untuk glukosa $\left(9,956 \times 10^{-3}\right)$ dan laktosa $\left(3,777 \times 10^{-3}\right)$. Perbedaan data percobaan dan pemodelan juga ditunjukkan pada Gambar 2 . Dari gambar tersebut juga dapat terlihat bahwa simpangan data terbesar ditunjukan oleh substrat glukosa. Sedangkan pada substrat galaktosa, data percobaan jauh lebih mendekati model.

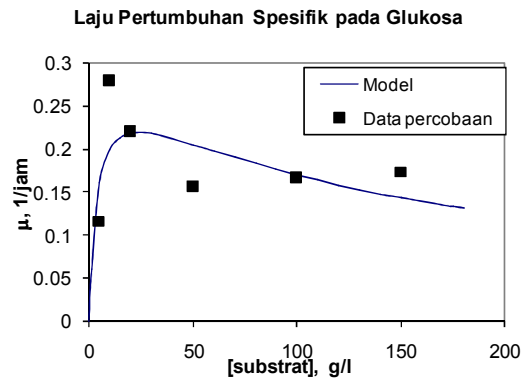

(a)

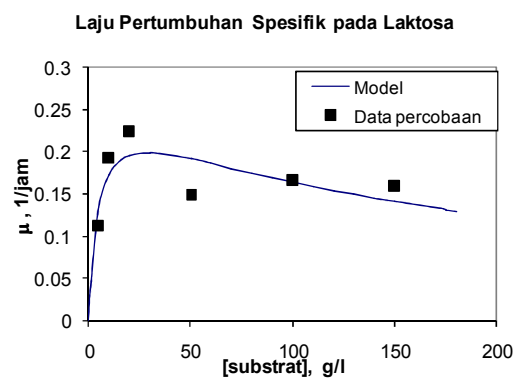

(b)

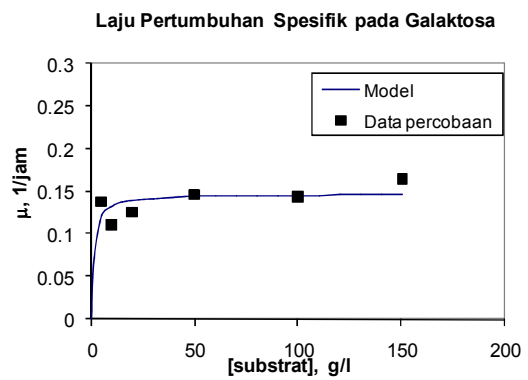

(c)

Gambar 2. Profil laju pertumbuhan spesifik dari model dan data percobaan terhadap substrat

$\begin{aligned} & \text { (a) glukosa (b) laktosa dan (c) } \\ & \text { galaktosa }\end{aligned}$

\section{Kesimpulan}

Profil pertumbuhan ragi pada substrat glukosa dan laktosa menunjukkan adanya inhibisi substrat, sedangkan pada profil pertumbuhan pada substrat galaktosa, inhibisi substrat tidak tampak. Pemodelan kinetika pertumbuhan ragi Kluwvromyces lactis FNCC 3024 telah dilakukan untuk tiga jenis substrat yaitu glukosa, laktosa, dan galaktosa. Model kinetika inhibisi substrat kompetitif tidak dapat digunakan untuk substrat glukosa dan laktosa. Model kinetika inhibisi subtrat nonkompetitif lebih tepat digunakan untuk substrat glukosa dan laktosa dengan kuadrat beda yang cukup kecil yaitu 9,956 x 10-3 untuk glukosa dan 3,777 x 10-3 untuk laktosa. Model kinetika Monod untuk substrat galaktosa memberikan jumlah kuadrat residual terkecil yaitu 1,358 x 10-3. Laju pertumbuhan spesifik maksimum yang dihasilkan dari pemodelan untuk substrat glukosa, laktosa dan galaktosa berturut-turut adalah $0,295,0,265$, dan 0,147 jam $^{-1}$.

\section{Ucapan Terima Kasih}

Penulis mengucapkan terima kasih pada Henrie Kurniawan dan Cecillia Kurniawati untuk data percobaan dalam penulisan makalah ini. Ucapan terima kasih juga penulis sampaikan pada Endah Asmawati, S.Si, M.Si atas masukannya pada proses pemodelan.

\section{Daftar Notasi}

$\mathrm{K}_{\mathrm{S}} \quad$ konsentrasi substrat $\quad[\mathrm{g} / \mathrm{L}]$

dimana $\mu=1 / 2 \mu_{\mathrm{m}}$

$\mathrm{K}_{\mathrm{I}} \quad$ konsentrasi substrat $\quad$ g/L]

dimana substrat mulai

menghambat

pertumbuhan

OD optical density

(absorbansi broth)

$\mathrm{S} \quad$ konsentrasi substrat [g/L]

$\mathrm{t}$ waktu [jam]

$\mathrm{t}_{0} \quad$ waktu awal fase [jam]

eksponensial

$t_{t} \quad$ waktu akhir fase [jam]

$\mathrm{X}$ konsentrasi sel [g/L]

$\mathrm{X}_{0} \quad$ konsentrasi sel awal fase $\quad[\mathrm{g} / \mathrm{L}]$ eksponensial

$\mathrm{X}_{\mathrm{t}} \quad$ konsentrasi sel akhir fase $\quad[\mathrm{g} / \mathrm{L}]$ eksponensial

[substrat] konsentrasi substrat $\quad[\mathrm{g} / \mathrm{L}]$

$\mu \quad$ laju pertumbuhan $\quad\left[\mathrm{jam}^{-1}\right.$ ]


Model Kinetika Inhibisi Substrat (Akbarningrum Fatmawati)

\begin{tabular}{|c|c|c|c|}
\hline & spesifik & & whey, Biomass and Bioenergy, 1997, Vol. \\
\hline$\mu_{\mathrm{m}}$ & $\begin{array}{l}\text { Laju pertumbuhan } \\
\text { spesifik maksimum }\end{array}$ & {$\left[\mathrm{jam}^{-1}\right]$} & $12(6), 461-472$ \\
\hline$\mu_{\text {perc }}$ & $\begin{array}{l}\text { Laju pertumbuhan } \\
\text { spesifik dari data } \\
\text { percobaan }\end{array}$ & {$\left[\mathrm{jam}^{-1}\right]$} & $\begin{array}{l}\text { Ghaly, A. E.; Kamal, M.; Correia, L. R., Kinetic } \\
\text { modelling of continuous submerged } \\
\text { fermentation of cheese whey for single cell }\end{array}$ \\
\hline$\mu_{\text {model }}$ & $\begin{array}{l}\text { Laju pertumbuhan } \\
\text { spesifik dari percobaan }\end{array}$ & {$\left[\mathrm{jam}^{-1}\right]$} & 2005, Vol. 96(10), 1143-1152. \\
\hline
\end{tabular}

\section{Daftar Pustaka}

Chapra, S. C.; Canale, R. P., Numerical Methods for Engineers; McGraw-Hill, 1988; 358-362.

Ghaly, A. E.; Taweel, A. E., Kinetic modelling of batch production of ethanol from cheese whey, Biomass and Bioenergy, 1994, Vol. 6(6), 465478.

Ghaly, A. E.; Taweel, A. E., Kinetic modelling of continuous production of ethanol from cheese

Kargi, F.; Ozmihci, S., Utilization of cheese whey powder (CWP) for etlianol fermentation: effect of operating parameters, Enzyme and Microbial Technology, 2005, Vol. 38(5), 711718.

Shuler, M. L.; Kargi, F., Bioprocess Engineering Basic Concepts; Prentice Hall, 1992.

Zafar, S.; Owais, M., Ethanol production from crude whey by Kluyveromyces marxianus, Biochemical Engineering Journal, 2006, Vol. 27(3), 295-298. 